\title{
¿La villa de Bilbao frente al señorío de Vizcaya (1750-1840)?
}

\author{
Pilar feijoo Caballero *
}

Bilbao es, en la etapa que analizamos de hecho, aunque no de derecho, la capital de Vizcaya. En la Villa han fijado su residencia el corregidor y la Diputación general, al tiempo que su Ayuntamiento e llustre Consulado son dos instituciones fundamentales en la regulación de la vida política y económica vizcaína.

El gobierno de Vizcaya se ejerció a través de tres instituciones: Juntas generales, Gobierno universal o Regimiento y Diputación general. Las Juntas generales, asamblea o parlamento del Señorío, estaban formadas por los representantes de más de cien entidades que, salvo casos excepcionales, se reunieron en la villa de Guernica. Estas reuniones, que se prolongaban a lo largo de una semana, solían celebrarse dos veces al año pero, a partir de la segunda mitad del setecientos, las Juntas se convocaron únicamente cada dos años. Dominar las Juntas fue la preocupación primera de los más poderosos señores de Vizcaya, porque desde época muy temprana su misión fundamental fue la elección del Regimiento o Gobierno universal que, siempre bajo la presidencia del corregidor, constituyó el verdadero poder ejecutivo del Señorío. $Y$ es que las Juntas, dada su lata composición, se reunian muy de tarde en tarde, con crecidos gastos y viéndose Vizcaya con frecuencia ayuna de poder. Por ello y hacia 1500 , se ideó una nueva fórmula: la formación de un órgano más reducido, más fácil de reunir y menos costoso, aunque siempre delegado de Juntas generales. Este órgano recibió el nombre de Regimiento o Gobierno universal y se formó, bajo la presidencia del co-

* Profesora titular de Historia Moderna de la Universidad de Deusto. 
rregidor, con varios diputados, regidores, síndicos y secretarios. Mas muy pronto, también, el Regimiento demostró poseer escasa agilidad por un excesivo número de miembros, con domicilios diversos que impedian reuniones prontas, en casos de urgencia. Surgió entonces la idea de un Regimiento más restringido, delegado del general que, a partir de 1645 , recibió el nombre de Diputación. Ésta fijó su residencia en Bilbao. Con la Diputación fueron llegando a la villa del Nervión los hombres más poderosos de Vizcaya $y$, muy pronto, de ser meros residentes, pasaron a ocupar los puestos directivos de sus dos instituciones básicas, del Ayuntamiento y del Consulado.

La Diputación general ejerció desde el primer momento el poder supremo en Vizcaya. Presidía, juntamente con el corregidor, las Juntas generales, con voz aunque sin voto; las convocaba y era la encargada de dar cumplimiento a sus acuerdos; fue jefe militar $y$, con frecuencia, supremo jefe político; recaudó las rentas y arbitrios provinciales; dispuso de sus fondos; cuidó de la protección y seguridad pública de la conservación de los caminos; atendió a la beneficiencia, etc. Fue, en suma, autoridad suprema, aunque, siempre, delegada de las Juntas generales

Ahora bien, nosotros nos preguntamos ¿por qué fijó la Diputación su sede en Bilbao y no en Guernica, Marquina, Bermeo...? Porque Bilbao, dada su excepcional posición geográfica concentró muy tempranamente las principales actividades mercantiles, mineras e industriales del Señorio. Bilbao y su ría se constituyeron en la columna vertebral de Vizcaya. En Bilbao es la Geografía la que manda. El eje fluvial Ibaizabal-NerviónCadagua abre a la villa una serie de caminos que la relacionan fácilmente con la Meseta, Guipúzcoa (y de aqui a Francia), Santander, valle del Ebro y resto de Vizcaya. Ya tenemos una explicación del éxito bilbaíno: su rica red de comunicaciones terrestres. Pero, Bilbao es también un puerto marítimo de excepción, al abrigo de las furias del mar y del asalto de piratas y corsarios, pues «el puerto lo constituye el estuario, el abra y la ría, desde donde comienza el abrigo hasta donde permite el calado fondear los barcos" ${ }^{1}$. Bilbao fue asimismo la sede de una potente burguesía que, con la Casa de Borbón, alcanzó mayor poder, prestigio y fortuna. p. 297.

M. Ciriquiain-Gaiztarro, Los puertos marítimos vascongados. San Sebastián 1951, 
Por todo ello, al ser la Villa la sede del corregidor de la Diputación, del Consulado y del más importante Ayuntamiento vizcaíno, instituciones todas dominadas por los «notables», nada puede extrañar que la Historia haya presentado a la Villa como el ente dominador del Señorío y que los conflictos internos vividos por Vizcaya se hayan, una y otra vez, traducido como luchas entre la Villa y la Tierra Llana.

De ahí que, y teniendo en cuenta que el gobierno del Señorío se ejerció a través de las tres instituciones citadas - Juntas, Regimiento y Diputación - nos interesa, aunque de forma sucinta, conocer su composición, normas que las regularon y funcionamiento.

Las Juntas generales estaban formadas por los representantes de más de 100 entidades con al menos un voto, quedando la Tierra Llana especialmente favorecida sobre todas los demás componentes. La prepotencia de la Tierra Llana se hace particularmente visible en relación al poder de las villas y ciudad de Orduña y, sobre todo, con respecto a Bilbao, como puede verse en el siguiente cuadro, elaborado por Monreal Cía, para 1712:

\begin{tabular}{lrrr}
\hline & Fogueras & $\%$ & Votos \\
\hline Tierra Llana & 5.785 & 46 & 72 \\
Villas y ciudad & 3.916 & 31 & 21 \\
M. de Durango & 684 & 6 & 2 \\
Repúblicas unidas & 1.028 & 8 & 5 \\
Repúblicas no unidas & 1.168 & 9 & 1 \\
\hline \multicolumn{1}{c}{ TOTAL } & 12.581 & 100 & $101^{2}$ \\
\hline
\end{tabular}

El $46 \%$ de la población ostentó más del $70 \%$ de los votos; las villas, $31 \%$ del total, sólo el $20 \%$ y Bilbao, con 1.300 fogueras, más del $10 \%$, tuvo un solo voto y así continuó hasta el final del régimen foral, pese a que su población aumentó a un ritmo muy superior a la de Vizcaya. No es menos cierto que «la villa encontró... medios de compensar este defecto ya que disponía de otros cauces para canalizar su influencia en la vida política del Señorio ${ }^{3}$. Opinión que se confirma, aparente-

2 G. Monreal Cia, Las instituciones públicas del Señorio de Vizcaya. (Hasta el siglo XVIII). Bilbao 1974, p. 339.

3 Ibidem, p. 339. 
mente al menos, en los cuadros que hemos elaborado y que presentamos a continuación, donde, a lo largo de esos 90 años, los "bilbaínos", ciertos «bilbainos», parecen dominar el Gobierno universal, al tiempo que controlan el Consulado y el Ayuntamiento.

\section{NOTAS ACLARATORIAS A LOS CUADROS}

\section{Participación de los «notables bilbaínos» en el Gobierno universal del Señorío}

El Gobierno universal del Señorío, elegido en Juntas generales, para mandatos bianuales, se constituyó con los siguientes cargos:

1. Los Diputados generales: fueron cuatro hasta 1790, y seis a partir de esta fecha. Actuaron únicamente dos, el primero de cada bando (oñacino y gamboíno), quedando los demás como suplentes. Residen en Bilbao.

2. Regidores electos: fueron ocho hasta 1789 , y seis a partir de este año. Desaparecen entre 1810 y 1814,1820 y 1823 , y de 1836 a 1839.

3. Regidores en suerte: sustitutos de los anteriores.

4. Síndicos: cuatro por bando hasta 1802 , y seis a partir de esta fecha, quedando reducidos a dos en las etapas constitucionales, o desapareciendo en algunos años.

5. Secretarios: funcionarios que tienen la calidad de escribanos reales. El que residía en Bibao ejerció la función. Dos por bando hasta 1796, en que aparece la figura del secretario perpetuo, jefe de los demás secretarios y archivero. Desde 1802, tres escribanos por bando; bajo el dominio napoleónico, un solo secretario, denominado secretario de Gobierno.

6. Consultores: como cargo aparece en 1764 (dos por bando). Letrados asesores del Gobierno. Desde 1790 hay un "consultor perpetuo", que según Areitio era "el oráculo del Derecho, usos y costumbres y tradiciones del País".

En los cuadros siguientes tenemos en cuenta únicamente a diputados, regidores electos y en suerte, síndicos y secretarios. 
Abreviaturas utilizadas:

- Dip. Ge. = Diputado general.

- Dip. Prv. = Diputado provincial $($ no hay régimen foral).

- Dip. Cor. = Diputado a Cortes (idem).

- Dip. Prop. = Diputado propietario (idem).

- Reg. El. = Regidor electo.

- Reg. $\mathrm{E} / \mathrm{s}=$ Regidor en suerte.

- Secrets. $=$ Secretarios.

Fuentes manejadas:

AMB (Archivo Municipal Bilbao), Libros de Decretos, 1750 a 1840.

Actas impresas de Juntas generales de Vizcaya, 1750 a 1839.

T. Guiard Larrauri, Historia del Consulado y Casa de Contratación de Bilbao y del comercio de la Villa, vol. II (1700-1830). Bilbao 1914, p. 884-890. (Contiene la relación completa de los priores y cónsules de dicha institución). 


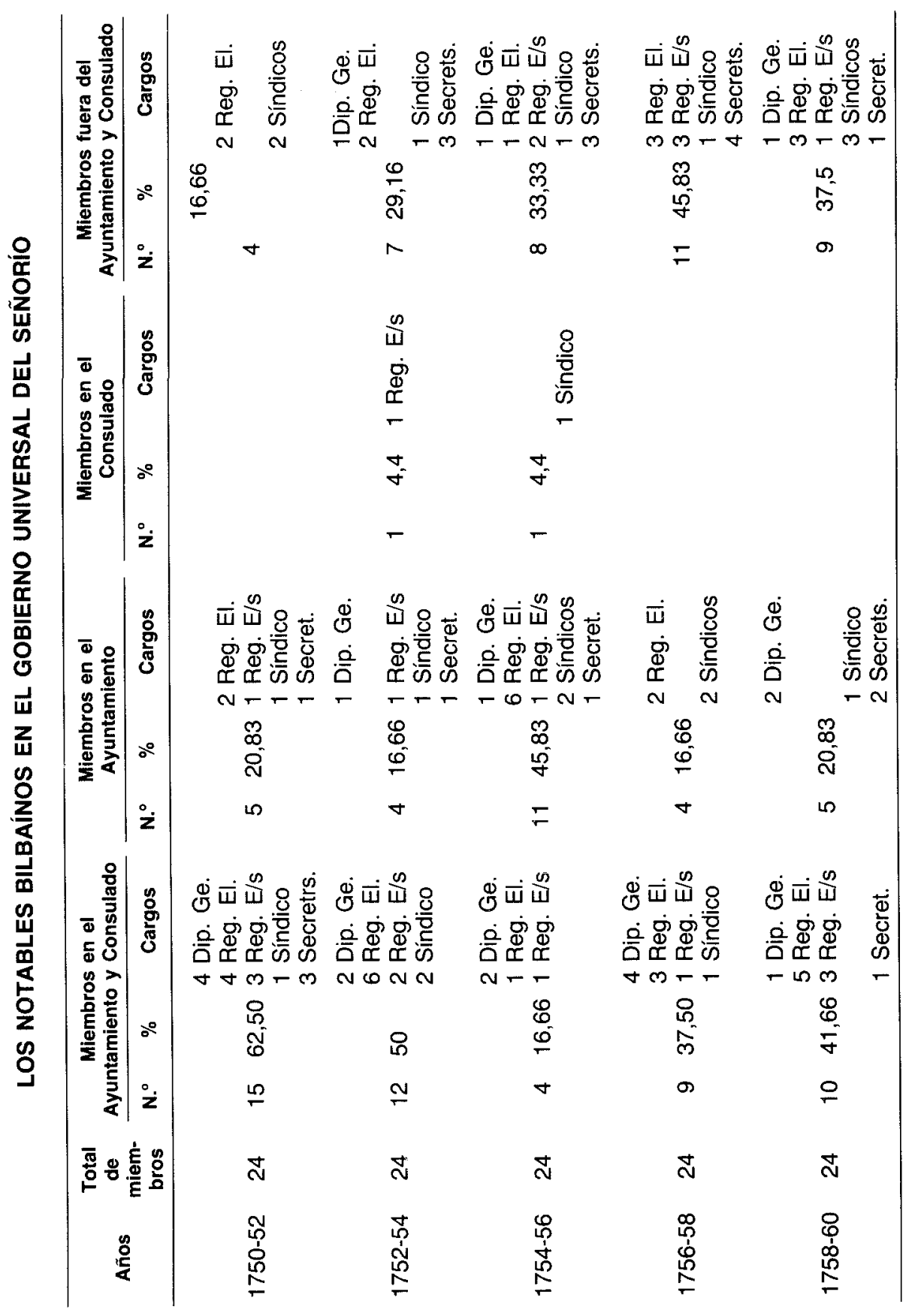




\section{PARTICIPACIÓN BILBAÍNA DE 1750 A 1760}

De un total de 120 cargos:

- 81 para la Villa $=67,5 \%$

- 39 para el Señorío $=32,5 \%$

Pero el reparto fue el siguiente:

- 17 Diputados generales $=85 \%$

- 29 Regidores electos $=72,5 \%$

- 14 Regidores en suerte $=70 \%$

- 12 Síndicos $=60 \%$

- 9 Secretarios $=45 \%$

En los bienios de 1752-54 y 1756-58, los dos diputados primeros fueron notables bilbaínos. 


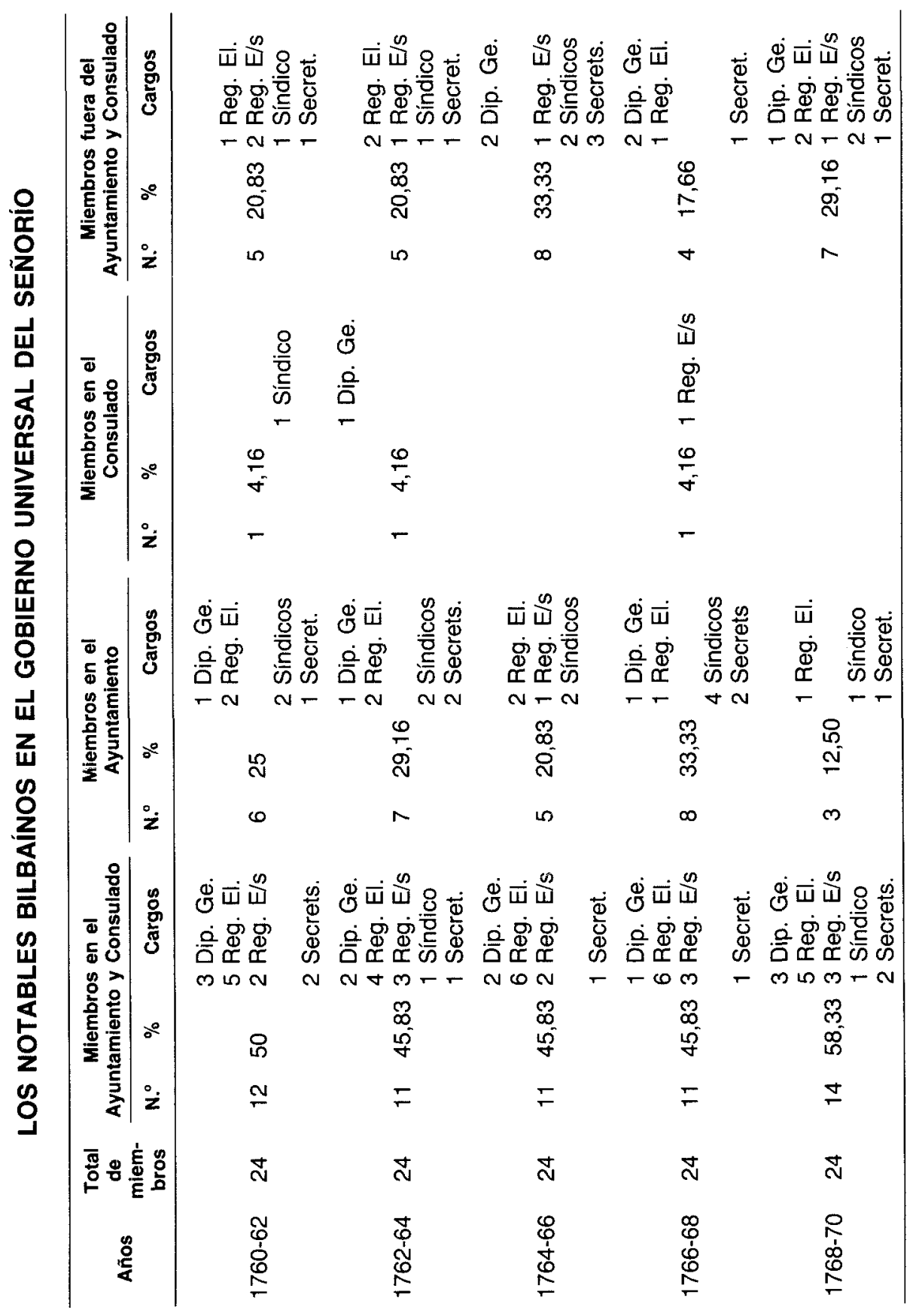




\section{PARTICIPACIÓN BILBAÍNA ENTRE 1760 Y 1770}

De un total de 120 cargos:

- 91 para la Villa $=75,8 \%$

- 29 para el Señorío $=24,2 \%$

Con el siguiente reparto:

- 15 Diputados generales $=75 \%$

- 34 Regidores electos $=85 \%$

- 14 Regidores en suerte $=70 \%$

- 14 Síndicos $=70 \%$

- 13 Secretarios $=65 \%$

En los bienios de 1762-64 y 1768-70, los diputados primeros fueron todos notables bilbaínos; por el contrario no lo fue ninguno en el de 176668 (¿efecto de los motines de 1766?). 


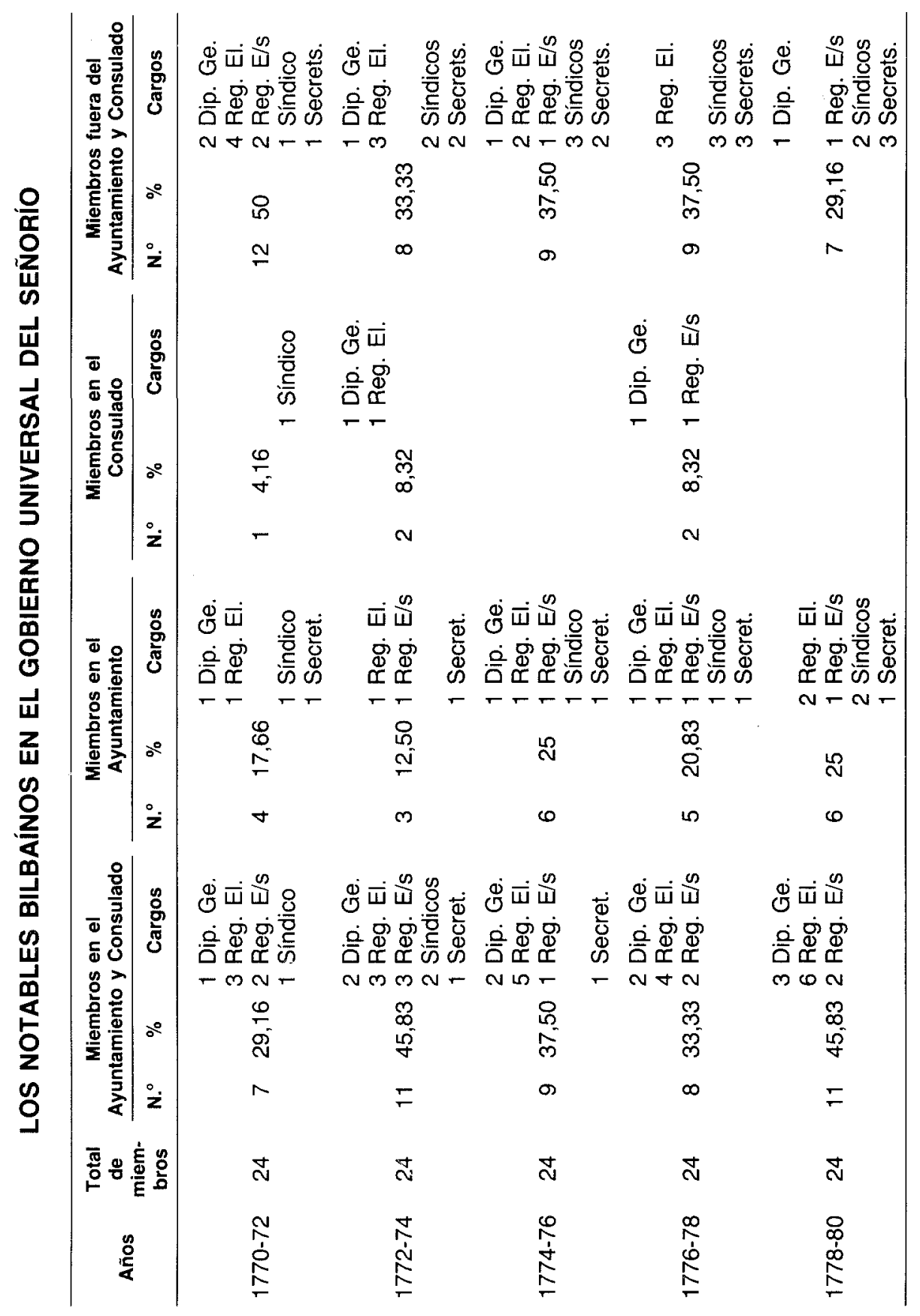




\section{PARTICIPACIÓN BILBAÍNA ENTRE 1770 Y 1780}

De un total de 120 cargos:

- 75 para la Villa $=62,5 \%$

- 45 para el Señorío $=37,5 \%$

Con el siguiente reparto:

- 15 Diputados generales $=75 \%$

- 25 Regidores electos $=62,5 \%$

- 18 Regidores en suerte $=90 \%$

- 10 Síndicos $=50 \%$

-7 Secretarios $=35 \%$

Pero de 1774 a 1800 , todos los diputados primeros fueron notables de Bilbao, con un total de ocho diputados primeros sobre los diez de la década. 


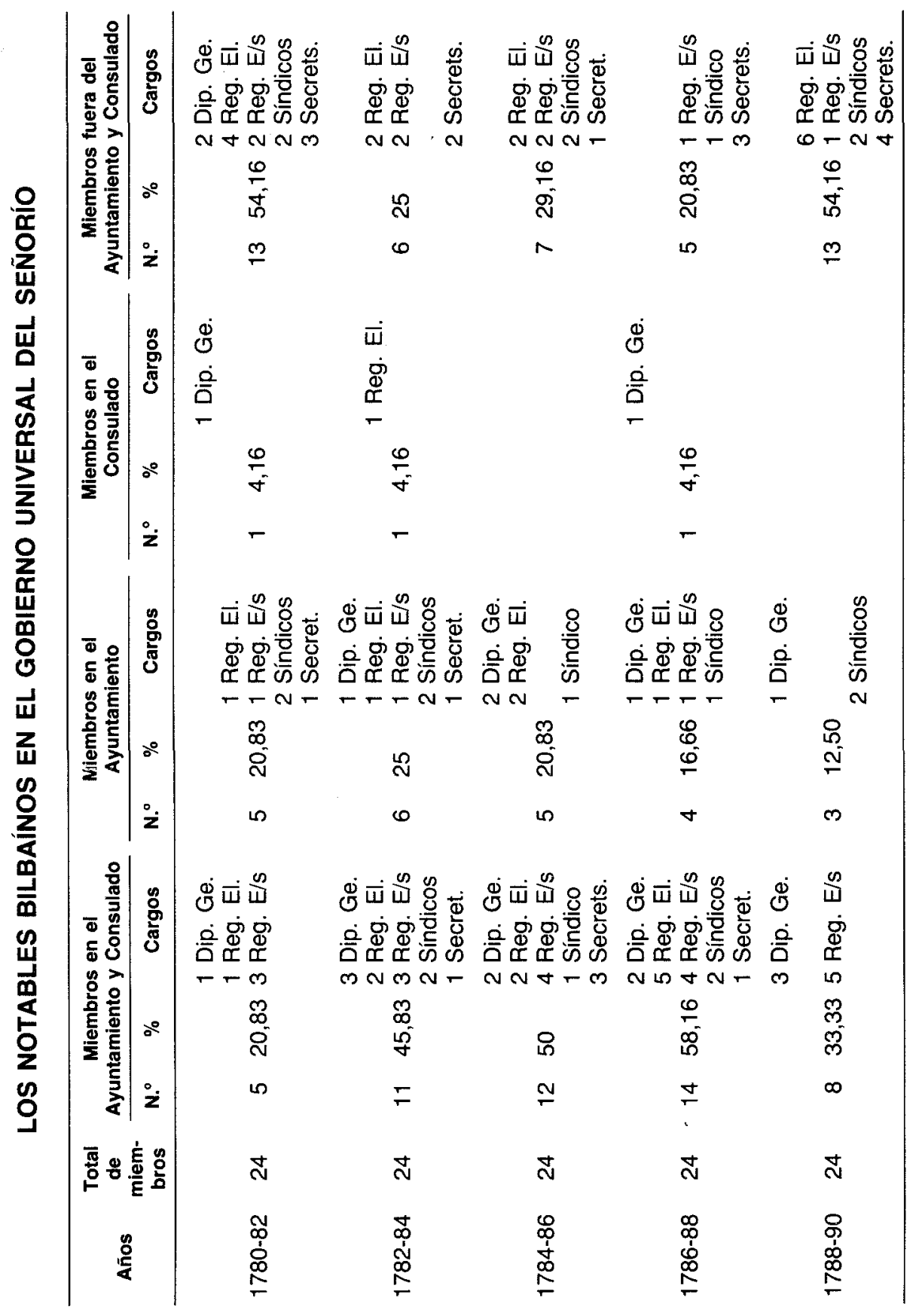




\section{PARTICIPACIÓN BILBAÍNA ENTRE 1780 Y 1790}

De un total de 120 cargos:

- 72 para la Villa $=60 \%$

- 48 para el Señorío $=40 \%$

Con el siguiente reparto:

- 14 Diputados generales $=70 \%$

- 16 Regidores electos $=53,33 \%$

-22 Regidores en suerte $=73,33 \%$

- 13 Síndicos = $65 \%$

- 7 Secretarios $=40 \%$

Pero los bilbaínos únicamente coparon cargos de diputados primeros en cuatro ocasiones, no figurando en el bienio de 1780 a 1782. 


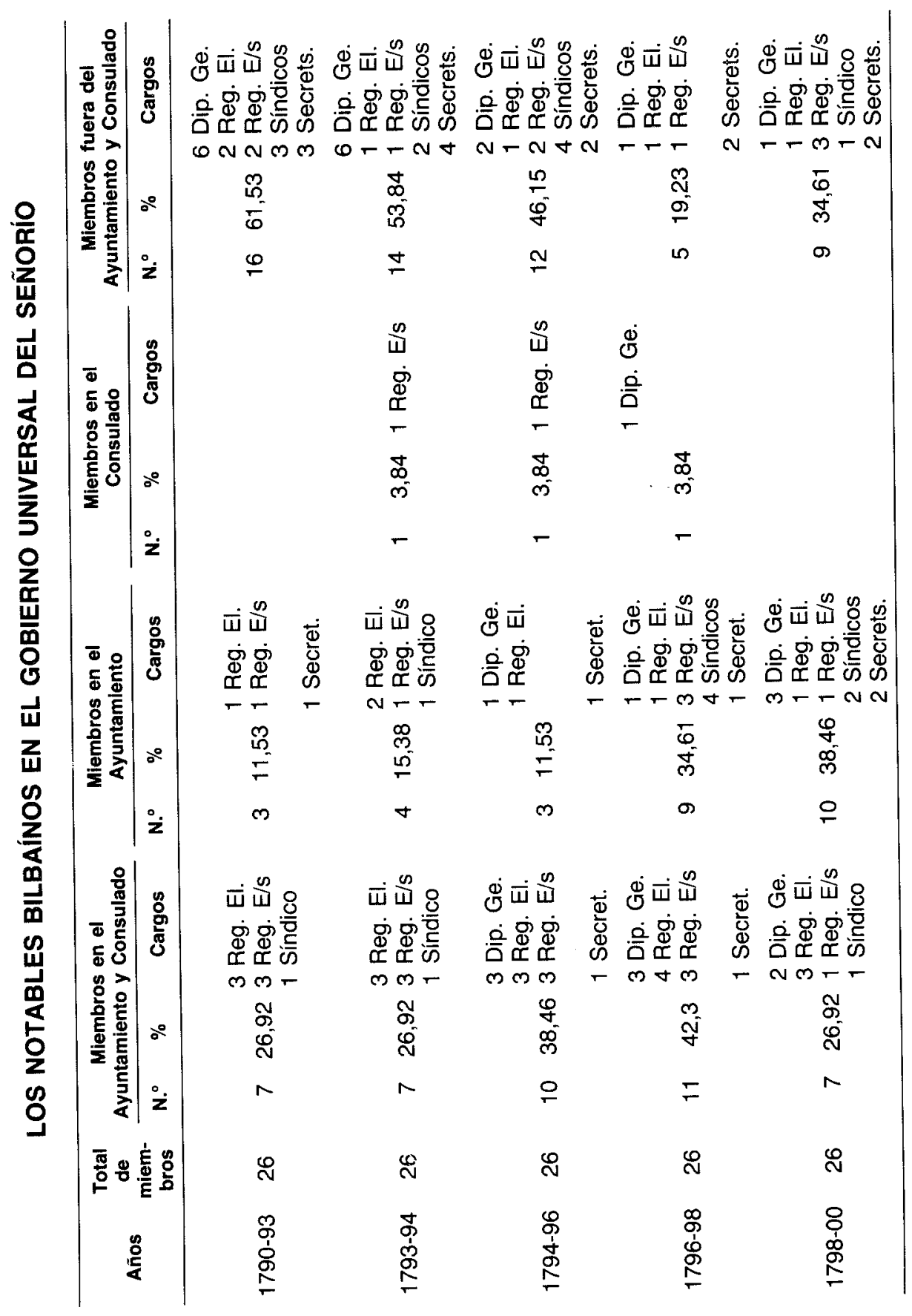




\section{PARTICIPACIÓN BILBAÍNA DE 1790 a 1800}

De un total de 130 cargos (2 diputados más por bienio):

- 86 para la Villa $=66,1 \%$

- 44 para el Señorío $=33,9 \%$

Pero el reparto fue el siguiente:

- 21 Diputados generales $=70 \%$

- 21 Regidores electos $=70 \%$

- 23 Regidores en suerte $=76,66 \%$

- 12 Síndicos $=60 \%$

- 9 Secretarios $=45 \%$

Ningún bilbaíno entre los primeros diputados, entre 1790 y 1794 , consecuencia del enfrentamiento entre Villa y Diputación (un largo pleito). 


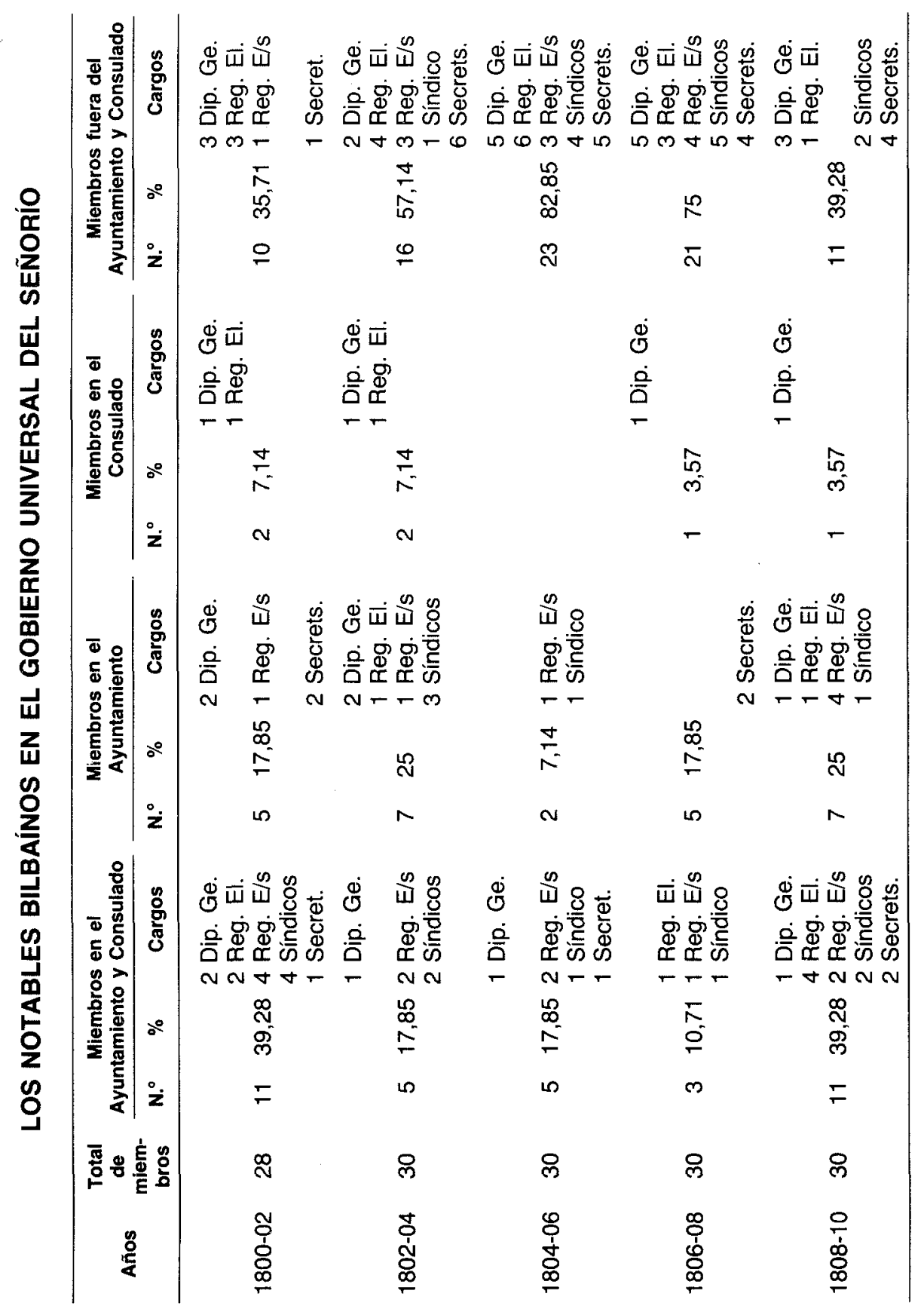




\section{PARTICIPACIÓN BILBAÍNA ENTRE 1800 Y 1810}

De un total de 132 cargos:

- 69 para la Villa $=52,2 \%$

- 63 para el Señorío $=47,8 \%$

Con el siguiente reparto:

- 14 Diputados generales $=43,7 \%$

- 13 Regidores electos $=43,3 \%$

- 19 Regidores en suerte $=63,3 \%$

- 13 Síndicos $=43,3 \%$

- 9 Secretarios $=30 \%$

En cuatro bienios - salvo el de 1806 a 1808 - tuvieron los bilbaínos un primer diputado general, sin duda consecuencia de la Zamacolada. 


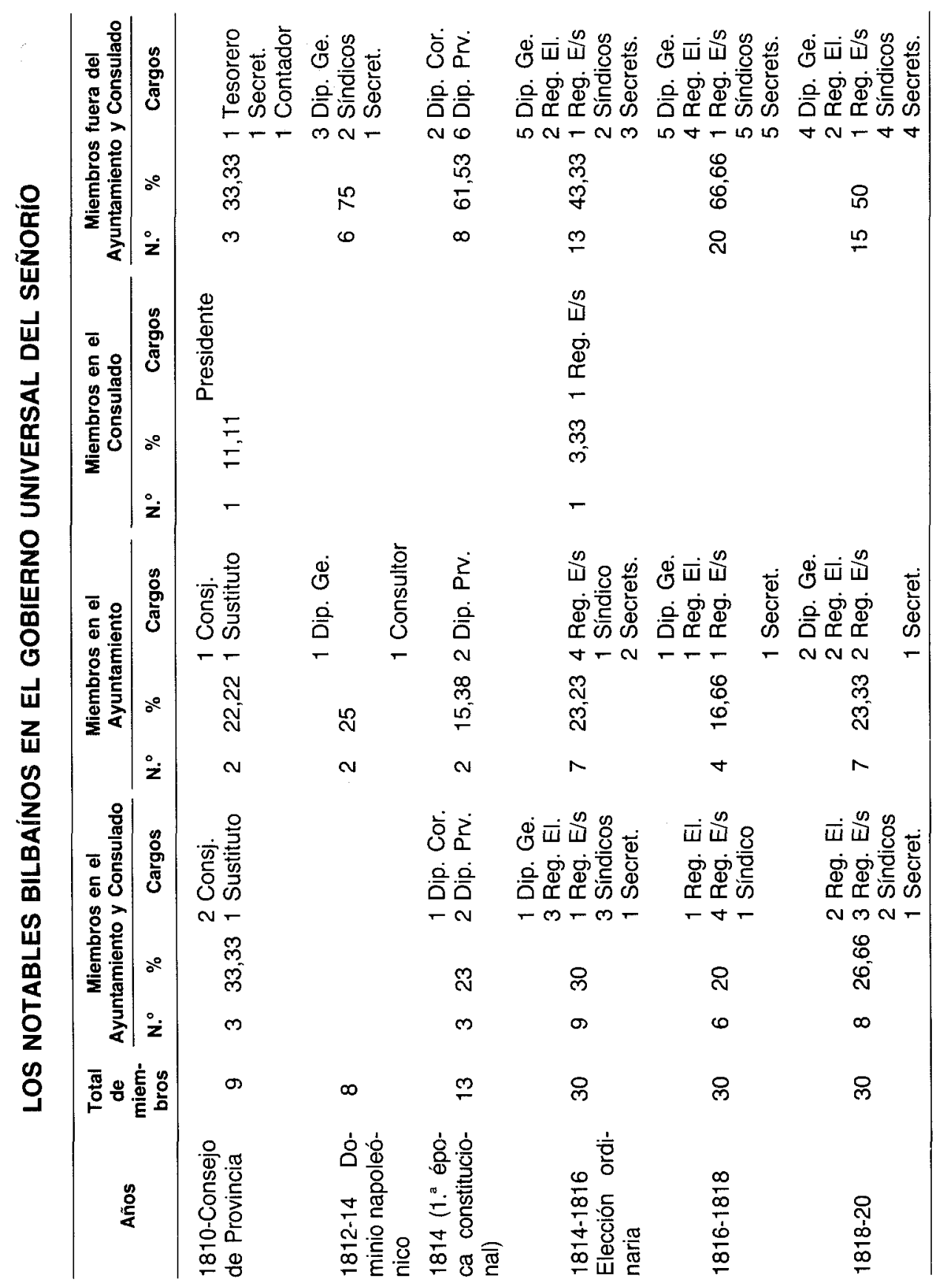




\section{PARTICIPACIÓN BILBAÍNA ENTRE 1810 y 1820}

De un total de 120 cargos:

- 54 para la Villa $=45 \%$

- 66 para el Señorío $=55 \%$

Con el siguiente reparto:

- 16 Diputados (con distintos nombres) $=47 \%$

- 10 Regidores electos $=48 \%$

- 15 Regidores en suerte $=83,3 \%$

- 7 Síndicos $=35 \%$

- 6 Secretarios $=20 \%$

El predominio de notables no bilbaínos es, en este periodo indudable, pero lo interesante es ver como dominan igualmente durante la época napoleónica, constitucional y absolutista. 


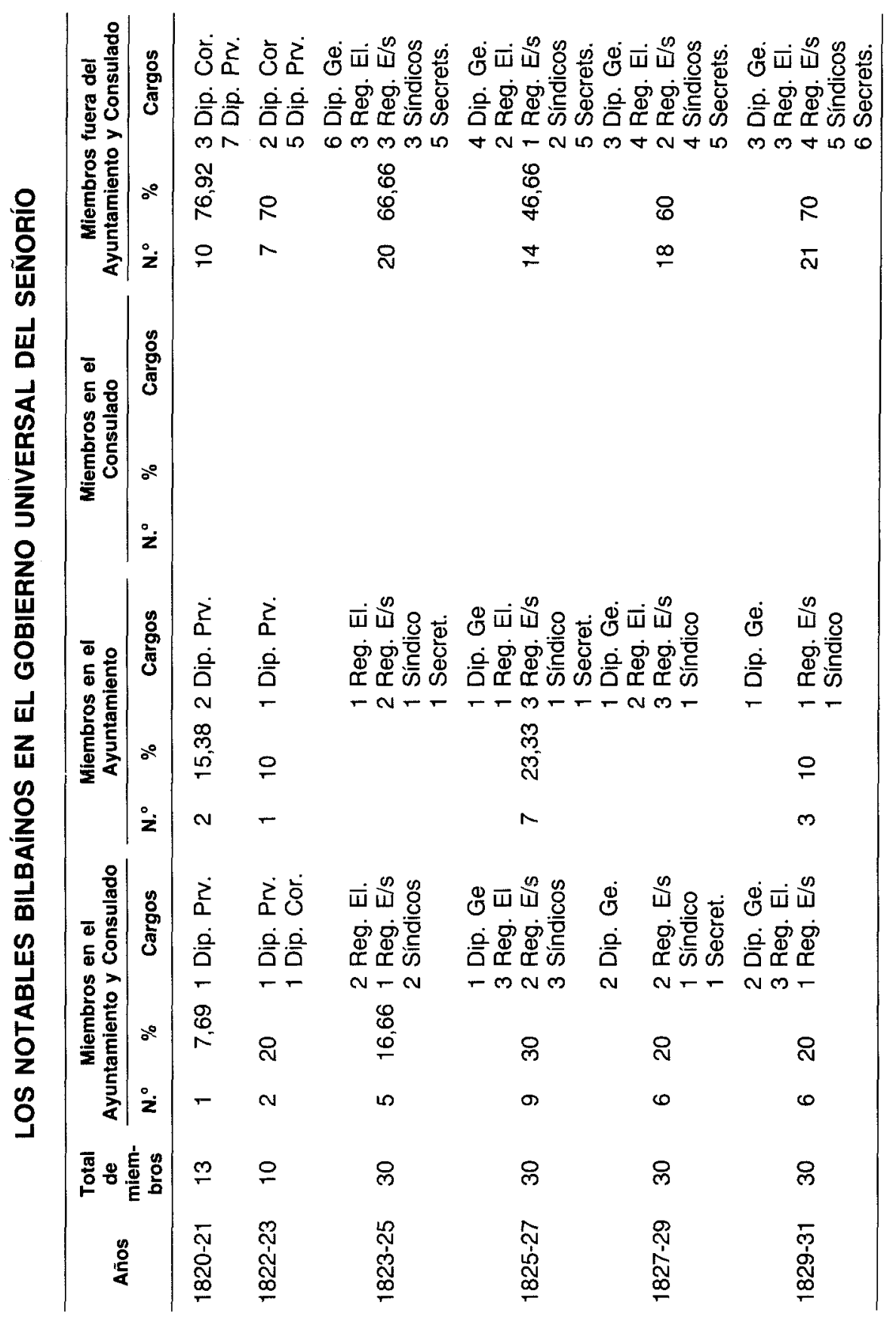




\section{PARTICIPACIÓN BILBAÍNA ENTRE 1820 Y 1831}

De un total de 143 cargos:

- 42 para la Villa $=31,5 \%$

- 91 para el Señorío $=68,5 \%$

Con el siguiente reparto:

- 16 Diputados (de distinta denominación) $=43 \%$

- 12 Regidores electos $=50 \%$

- 14 Regidores en suerte $=58 \%$

- 10 Síndicos $=41 \%$

- 3 Secretarios $=12 \%$

El peso de la Villa ha disminuido de forma importante, aunque se conserve a niveles todavía muy aceptables. Los hombres ligados al Consulado han desaparecido de la escena política provincial. Triunfo de las clases propietarias. 


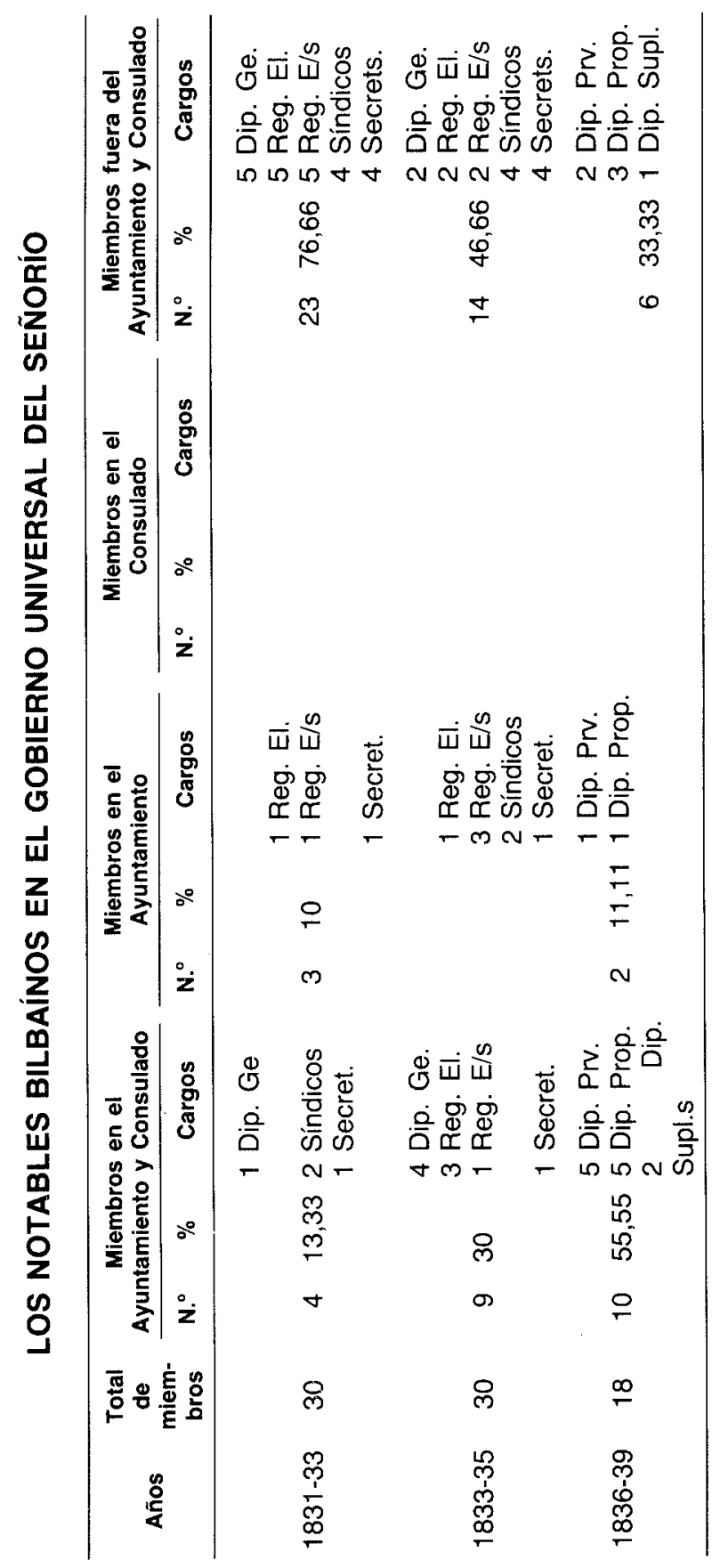




\section{PARTICIPACIÓN DE LOS BILBAÍNOS ENTRE 1830 Y 1839}

De un total de 78 cargos:

- 35 para la Villa $=44,8 \%$

- 43 para el Señorío $=55,2 \%$

Con el siguiente reparto:

- 11 Diputados $=55 \%$

- 5 Regidores electos $=41,6 \%$

- 4 Regidores en suerte $=33,3 \%$

- 4 Síndicos $=33,3 \%$

- 4 Secretarios $=33,3 \%$

La Villa domina por la cabeza, menos en los años de 1831 a 1833 en que está en franca minoría.

En cuanto a los consultores, que no hemos reflejado en los cuadros, podemos afirmar que casi al 100 por 100 fueron juristas íntimamente relacionados con las instituciones públicas de la Villa de Bilbao. 
La siempre importante presencia de los notables «bilbaínos" queda confirmada en los cuadros precedentes. Pero nosotros creemos que esos cuadros tienen otra lectura: ¿Es Bilbao quien domina al Señorío o Bilbao ha sido previamente dominado? La pregunta no es baladí, se sustenta en el análisis de los requisitos exigidos, para ocupar los cargos directivos, por las instituciones públicas de Bilbao y de Vizcaya; en el estudio de quiénes fueron esos acaparadores del poder y de cuáles fueron sus comportamientos políticos, familiares y sociales.

Podemos adelantar una primera conclusión: los puestos de gobierno y administración, en sus más altos niveles, se reservaron a un reducido grupo: los ricos propietarios y mayorazgos, las gentes con vida noble, los honorables. $Y$ allí donde, caso de las Juntas generales, la condición de apoderado no exigió esas condiciones socioeconómicas, los notables todos, de Bilbao y de Vizcaya, supieron encontrar otros caminos que les entregaron los votos y las representaciones preceptivas.

En la teoría, la condición de apoderado en Juntas generales no excluyó a ningún vizcaino, aunque, desde principios del siglo XVII, se exigiera saber leer y escribir en romance. ¿Quién lo exigió? El Señorío, por boca de sus notables. Si esta exigencia se cumplió, la mayoría analfabeta y vascoparlante quedó excluida. Pero no fue por aquí por donde los ricos propietarios y mayorazgos se hicieron con las representaciones en Juntas generales. Los notables llevaron la voz de los pueblos unas veces, por ser sus alcaldes, síndicos o fieles; otras, por su calidad de vecinos propietarios o simplemente propietarios, aspecto éste de fundamental importancia; como simples sustitutos de los apoderados legítimamente elegidos; por tratarse de fieles en propiedad, caso no muy frecuente pero que, también se dio; por ser "socios" (término que no se aclara) de las autoridades municipales o como simples acompañantes de éstas, sin que, en ningún caso, se justifique la razón de su presencia y de su derecho a voto. Un conjunto de ardides que concentraron todos los poderes en un reducido grupo de personajes, frecuentemente emparentados entre sí, y de los que presentamos, por las exigencias de espacio de este trabajo, únicamente dos ejemplos, en las páginas finales.

Creemos que esta situación fue posible porque esa minoría rica era la dueña de la tierra y acalló la voz de los que para ella trabajaban. Decían, en 1796, las anteiglesias de Dima y Ubidea y la villa de Ochandiano, en sendos recursos elevados al Consejo de Castilla contra los acuerdos de Juntas generales, que: 
«Por descontado se percibe que los grandes propietarios que viven con opulencia en la Corte y otros pueblos fuera de Vizcaya, que por cálculo prudente absorven los dos tercios de quantas propiedades incluie este Señorío..." ${ }^{4}$.

Un poder que, hemos comprobado, fue también posible con el concurso de los profesionales del Derecho, portavoces "camuflados" de una rica e influyente clientela, muchas veces avecindada fuera de Vizcaya, a la que sin embargo nunca renunciaron a dominar.

El Gobierno universal y la Diputación general, elegidos por esas Juntas generales copadas por la oligarquía terrateniente, se formaron con sus afines. Pero, además, en ambas instituciones los requisitos legalmente establecidos dejaron un escaso margen de elección. Hay exigencias que no entrañan discriminación alguna: mayoría de edad, vecindad o nobleza, ya que todos los vizcaínos eran naturalmente nobles; quedaron, sin embargo, apartados los panaderos, los taberneros y todos los que ejercían oficios mecánicos, discriminaciones propias de una sociedad de Antiguo Régimen, que eso no fue la sociedad vizcaína en esos noventa años. $Y$ todo ello facilitó:

«La promoción a los que ostentaban alguna distinción especial de nobleza, como la pertenencia a las órdenes militares. Esta política normativa no debió ser del agrado general; el tema salió a relucir en más de una ocasión en las alteraciones populares que se siguieron a consecuencia del estanco de la sal» ${ }^{5}$.

$\mathrm{Y}$, en otras muchas ocasiones, como la matxinada de las aduanas de 1718, en las revueltas de $1766 \mathrm{y}$, desde luego, durante la guerra contra la Convención francesa.

Otros requisitos podríamos calificarlos de "aristocráticos", como estar en posesión de importantes bienes raíces. En Juntas generales de 1748 se fijaron, para los diputados, en veinte mil ducados, y en las de 1833 «la Diputación propuso que fuese circunstancia indispensable para

\footnotetext{
AHN, Estado, Leg. 67, n. 1-286, Letras A-D.

5 D. Areitio Mendiolea, El Gobierno universal del Señorio de Vizcaya. Bilbao 1943, p.
} 440. 
ejercer el cargo de Diputado, una renta de doce mil reales, procedentes de fincas radicantes en Vizcaya, pero la Junta dijo que debía exigirse la posesión o usufructo de cuarenta y cinco mil ducados de capital en fincas de Vizcaya, libres o vinculadas, y en vista de las divergencias quedó sin resolver la cuestión hasta el nuevo Reglamento de $1850 "{ }^{6}$. La reserva es bien clara: contar con bienes raíces en cuantía tan elevada significó ser parte de la alta nobleza rural o de la rica burguesía terrateniente. En una palabra, los menos.

Para los demás cargos —regidores, síndicos, secretarios, consultores y tesoreros- hubo parejas exigencias, aunque siempre en menor cuantía. Pero, en grados mayores o menores, todos formaron parte de los grupos dominantes.

Si del señorío pasamos a la villa de Bilbao, el panorama apenas cambia. En la Villa - Ayuntamiento y Consulado- se ha producido un proceso de "aristocratización», perfectamente definido en las Ordenanzas del Ayuntamiento de 1699 y en las del Consulado de 1737. Y debemos unir a ciertas condiciones o calidades de honorabilidad y fortuna, otras no menos importantes: la determinación de un cuerpo electoral tan reducido, que el poder se convierte en un juego de la minoría.

En el Ayuntamiento, fue condición «sine qua non» que: «los que han de ser Electos para gobernar República de tanto lustre, y Nobleza como esta Villa... tengan veinte y cinco años cumplidos, y mil ducados de hacienda, y de hallí arriba... ${ }^{7}$.

Por eso, en 1768, primera actuación de los oficios del común, diputado y síndico personero lograron que el Corregidor, como presidente de la corporación municipal, mudase este capítulo y que "los mil ducados de hacienda... pudieran serlo en dinero, bienes muebles..." ${ }^{8}$. Una burguesía mercantil, enriquecida al socaire de este siglo XVIII, se veía marginada de las regidurías por no ser «propietaria» de bienes raíces en Vizcaya o Bilbao, y tampoco encontraba facilidades para serlo. La tierra

Ibidem, p. 109 y ss.

Ordenanzas que tiene, usa y guarda la M.N. y M.L. Villa de Bilbao..., edic. de 1797 , p. 3.

${ }_{8}$ Archivo Municipal de Bilbao (en adelante AMB), Libro de Decretos de 1768, fol. 137 y ss. 
escaseaba, y el suelo urbano era propiedad de unos pocos, que no estaban dispuestos a venderlo.

Pero, no podrían ser elegidos todos aquellos que: «usen los unos, y otros oficios mecánicos..., traten en mantenimientos a menudo, ni los hagan vender, ni sean obligados a abastecer qualquier género de ellos, así en esta Villa como en otra parte, ni lugar remoto que sea; ni mesoneros..." ${ }^{9}$.

Ya tenemos dos impedimentos importantes: uno, por el patrimonio; otro, por la dignidad social. Y esto ocurría en una villa donde el número de mayorazgos y de alta burguesía era muy reducido ${ }^{10}$. Sin embargo, esa rica minoría dominante tuvo en sus manos la elección de los ayuntamientos. Pues ¿quién o quiénes elegían los 30 de diciembre de cada año a los nuevos ediles? Únicamente doce regidores, los doce regidores en activo, en la citada fecha. Si el campo de los elegibles no fue demasiado lato, el de los electores fue realmente mínimo. Aquellos doce regidores eligieron a sus sucesores entre sus afines. Un repaso a los ayuntamientos bilbaínos, entre 1750 y 1840, demuestra que sus miembros pertenecieron a los más altos estratos de aquella sociedad, burlándose una y otra vez las Ordenanzas municipales en punto a vecindad, mayoria de edad, asistencia a sus sesiones, etc. Pero el ayuntamiento, monolítico hasta los setenta, empezó a dar entrada a nuevos grupos, burguesía acomodada, desde luego, pero con afanes e ideales diferentes, y que intentó, con mediano éxito, hacerse con los oficios del común, cuya creación fue recibida de muy mal grado por el Ayuntamiento de Bilbao. Los que hasta entonces lo venian dominando comprendieron que los intentos "democratizadores" de Carlos III abrían la cancela de la Casa Consistorial a gentes de otro grupo, nuevos y molestos testigos de por quienes y para quienes se administraba y gobernaba la Villa. El Ayuntamiento dejó de ser un remanso de paz para convertirse en agitado campo de luchas y enfrentamientos entre sectores siempre poderosos, porque el pueblo no tuvo posibilidades de acceder al mismo.

Los poderosos de Bilbao no formaron un grupo homogéneo. Una minoría de ricos mayorazgos vivía de rentas y de censos; una alta burguesía combinaba las rentas y los censos con fuertes inversiones en el comercio de exportación e importación. Aparentemente, estos dos grupos

9 Ordenanzas de Bilbao, p. 4.

10 M. MAULEÓN ISLA, La población de Bibao en el sigio XVII. Valladolid 1961, p. 252. 
no mostraban diferencias: sus modos de vida eran parejos; estaban unidos con lazos de sangre; más instruida, más activa la alta burguesía. Todos eran propietarios, pero no siempre coincidian en sus afanes e intereses. Pero demostraron poseer espíritu de grupo, supieron unirse ante cualquier amenaza que pusiera en peligro su posición privilegiada. Por ello resulta muy difícil separarlos. Los ricos terratenientes gustaron de residir en Bilbao, cerca de las instituciones de poder; gozar del confort, de las diversiones, de las tertulias y de todas las comodidades que una Villa tan bien abastecida y relacionada podía darles. Pero también buscaron en la Villa del Nervión su propia seguridad personal; sus casas solariegas son repetidamente asaltadas, sus personas amenazadas; un pueblo, cada día más pobre, manifiesta así su desesperación y su miseria. En la Villa encontraron maridos para sus hijas y esposas para sus herederos, entre esa alta burguesía. Se tejen así unos estrechos lazos familiares, una tupida red de intereses que dificultan toda distinción. Dominaron el Ayuntamiento, pero no lo controlaron al 100 por 100 , porque una nueva burguesía, enriquecida recientemente, ajena a la propiedad urbana y rural, consigue introducirse y, en ciertos momentos, con bastante fuerza. Esta burguesía centra su interés en la Villa, no tiene otros intereses, y se enfrenta con la otra oligarquía, con los notables que, al fin y a la postre, serán siempre los verdaderos vencedores. Dominan Bilbao, pero no defienden los derechos de la Villa, no defienden sus intereses, se sirven de ella (obligación de consumir chacoli en las tabernas, su chacolí en detrimento de las sisas de la Villa por la introducción del vino foráneo; votan en Guernica contra Bilbao - 1792—, etc.) ${ }^{11}$.

En 1866, don Antonio Trueba rechazaba con las siguientes palabras la petición de Bilbao por obtener mayor número de votos en Juntas generales:

«La representación de Bilbao elegida solo por el Ayuntamiento y no por el voto directo de todo el vecindario... carece de una autoridad moral que tendría si la eligiese todo el vecindario y recibiese de este instrucciones sobre los asuntos que ha de promover o se han de tratar en las Juntas...»

"Bilbao domina Vizcaya toda de forma sencilla, pues "donde el propietario comunmente bilbaino, lejos de ser un tirano para el colono,

11 AMB, Libro de Decretos de 1792, fols. 134 a 139, sesión del 10 de julio. Los regidores Vitoria y Uríbarri reconocen haber votado, en Guernica, contra los intereses de la Villa, porque no están de acuerdo con sus planteamientos. 
es un protector, es un padre cariñoso..." los vecinos de los pueblos le dan su representación. Si Bilbao contara con mayor número de votos... dominaría al todo -el Señorio" ${ }^{12}$.

La respuesta de Bilbao llegó de inmediato:

"Si la memoria no nos ha traicionado y conservamos en ella con exactitud los nombres de los muy dignos Padres de Provincia, observamos que casi constantemente los primeros magistrados del Señorío han sido extraños a la metrópoli vizcaína» ${ }^{13}$.

Trueba no mentía; la respuesta que recibió, tampoco.

Bilbao dominaba y era dominada.

En el Consulado las Ordenanzas también reservaron sus puestos de gobierno a la alta burguesía y a la alta nobleza; solamente podrían ser elegidos aquellos que:

«hubieran nacido en estos Reynos, Hijos Dalgo, limpios de toda mala raza... hábiles y suficientes en las cosas del comercio y navegación... bien entendido que los "que viven de sus rentas, aunque no hayan pagado Avería, ni comercien, y aunque sean Caballeros de qualquiera de las Ordenes Militares, hayan de poder ser sorteados por Prior, Cónsules, y Consiliarios, según se ha practicado hasta aquí..."» ${ }^{14}$.

Reserva que se complementa cuando vemos que, todos aquellos que forman parte de lo que hoy día denominamos clases medias, quedan fuera de toda posible elección:

«Ni abogados, Escribanos, Procuradores, Médicos... Plateros, Corredores de Lonjas, Cambios y Navíos, Sastres, Zapateros; ni otros que tuvieren tales oficios, aunque estén pagando Avería..." ${ }^{15}$.

12 Euskalduna, edición del 21 de agosto de 1866.

13 Euskalduna, edición del 26 de agosto de 1866.

14 Ordenanzas de la llustre Universidad y Casa de Contratación de la M. N. y M.L. Villa de Bilbao... Año 1737, reimpresión. Madrid 1796, p. 36 у 37.

15 Ibidem, p. 36. 
$Y$ ¿quiénes tuvieron derecho de voto? Nuevamente, nos encontramos con reservas de tipo socioeconómico:

"Los Mercaderes actuales cargadores de Mar, que están pagando Avería por si mismos, o que habiéndola pagado, hubiesen tomado rumbo de tratar, y negociar con Fierro, Letras de Cambio, o dando dinero a interés, u otro semejante trato, y negociación superior, por haber mejorado de conveniencias; y los Capitanes, y Maestres de Naos, que fueren interesados en las mismas Naos que mandan, y tuvieren dicha vecindad, y domicilio en la Villa» ${ }^{16}$.

Estas Ordenanzas no precisan de comentarios. Las reservas y los rechazos son bien claros.

En conclusión, podemos afirmar que en Bilbao se dieron cita todas las clases sociales y todas las tendencias políticas. De Bilbao partió la rebelión realista de 1823, y también la defensa de la causa liberal; en Bilbao hubo afrancesados, furiosos y moderados constitucionalistas y no menos furiosos o moderados anticonstitucionalistas. Como decía un bilbaíno de pro «Bilbao fue la cuna de la causa de Don Carlos, Bilbao puede decirse que ha sido su sepulcro" ${ }^{17}$. El triunfo liberal de 1839 no hizo de la Villa un ente político monolítico. Siguió siendo la residencia preferida de los más poderosos señores de Vizcaya que, como decía el Ayuntamiento, en 1834, en oficio dirigido a la Reina Gobernadora, «la gente de alguna valía es en su inmensa mayoría conocidamente adicta a la justa causa de la legitimidad" ${ }^{18}$. Así fue, con algunas excepciones. Los notables de Vizcaya fueron mayoritariamente liberales y siguieron gustando de residir en la villa del Nervión; y así se forja esa visión de un Bilbao dominador, prepotente, enfrentado a la Tierra Llana. Nada importa que la Villa viviera sus propias luchas civiles, que hubiese bilbaínos de todos los credos políticos. Bilbao alberga a los dueños de la tierra, a los que dominaban la Diputación, el Gobierno universal y las Juntas generales. Nada más fácil que decir: Villa contra Tierra Llana. El mito se puso en marcha, y nadie lo discutió. Era una fácil y cómoda explicación para

16 Ibidem, p. 35.

1 F. DE HORMAECHEA, “Bilbao», Viaje pintoresco por las Provincias vascongadas, de J. E. Delmas. Bilbao 1846.

${ }_{18} \mathrm{AMB}$, Libro de Decretos de 1834, fol. 815 . 
unos problemas nada cómodos ni fáciles; las explicaciones simples casi siempre encuentran una amplia audiencia. 


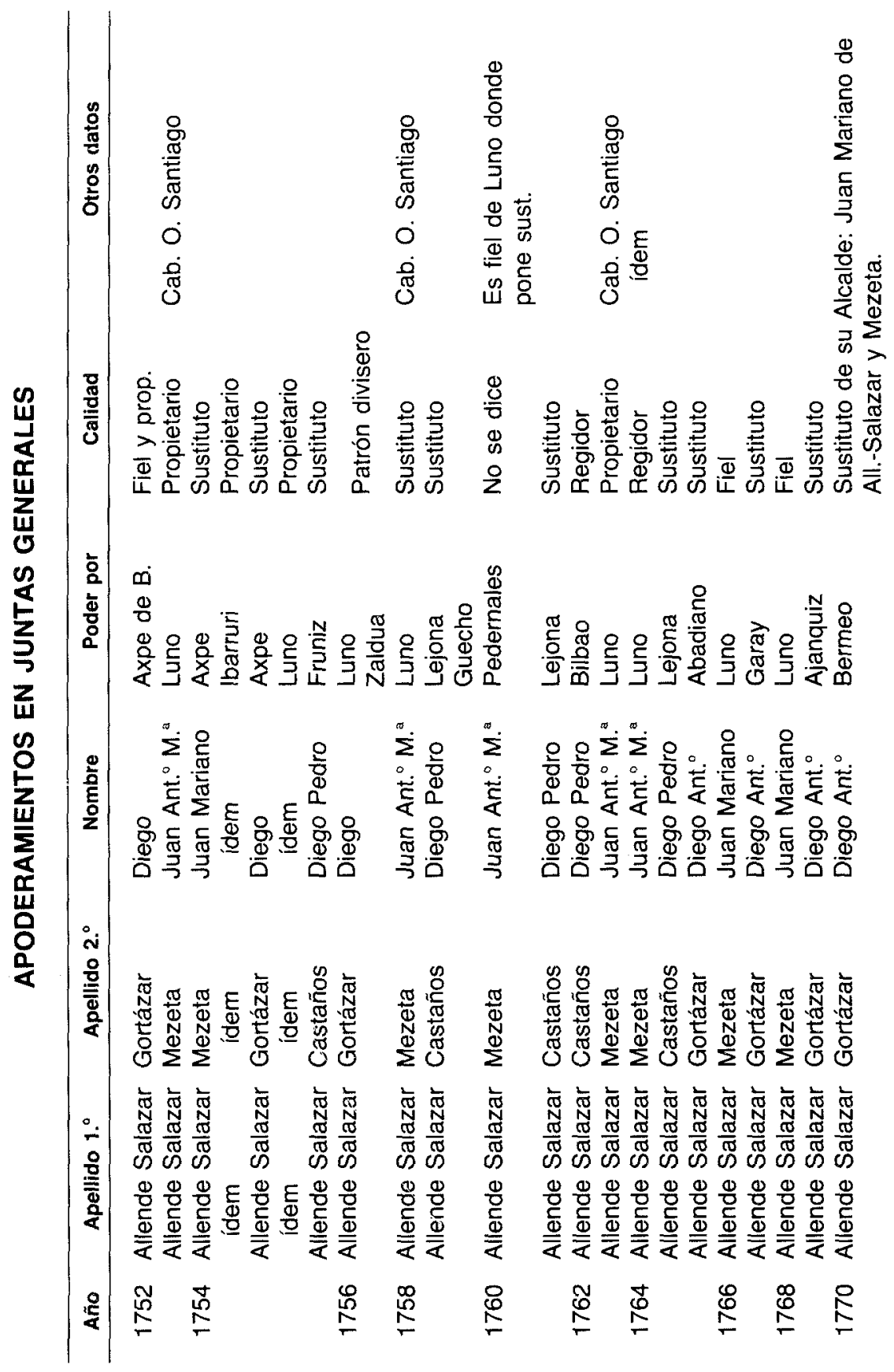




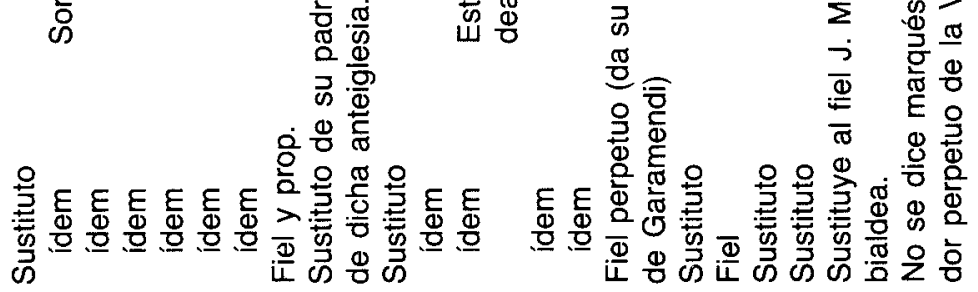

을

흔

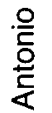

守

ब्ञ

অ্口

$\stackrel{\varpi}{\varpi}$

$\bar{\Phi}$

¿

(⿻)

a

$\stackrel{9}{2}$

0

ஷ

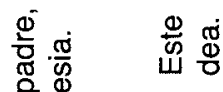

产

a

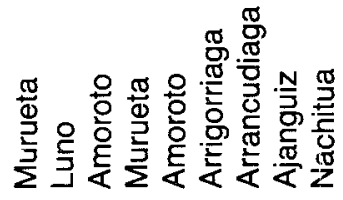

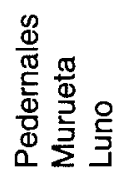

올올 올

옹 읗 월

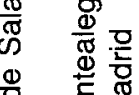

焉 $\sum_{0}^{0} \sum_{0}^{\frac{\pi}{2}}$

实

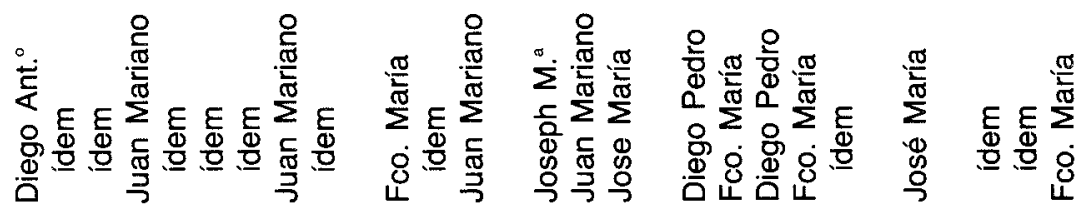

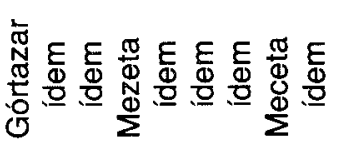

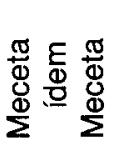

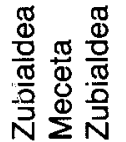

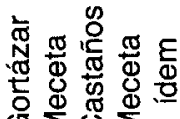

$\frac{\pi}{\frac{\pi}{0}}$

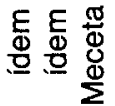

胥

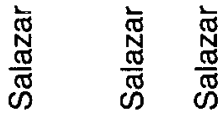

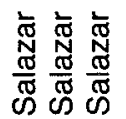

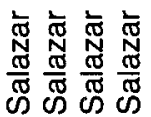

敢

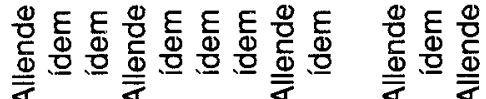

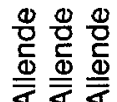

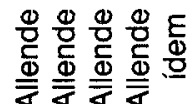

$\frac{\mathbb{8}}{\frac{0}{0}}$

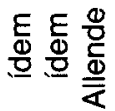

$\stackrel{5}{\stackrel{N}{N}}$

$\frac{\sqrt{2}}{N}$

$\stackrel{\infty}{\stackrel{1}{上}}$

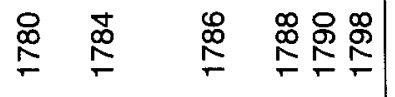




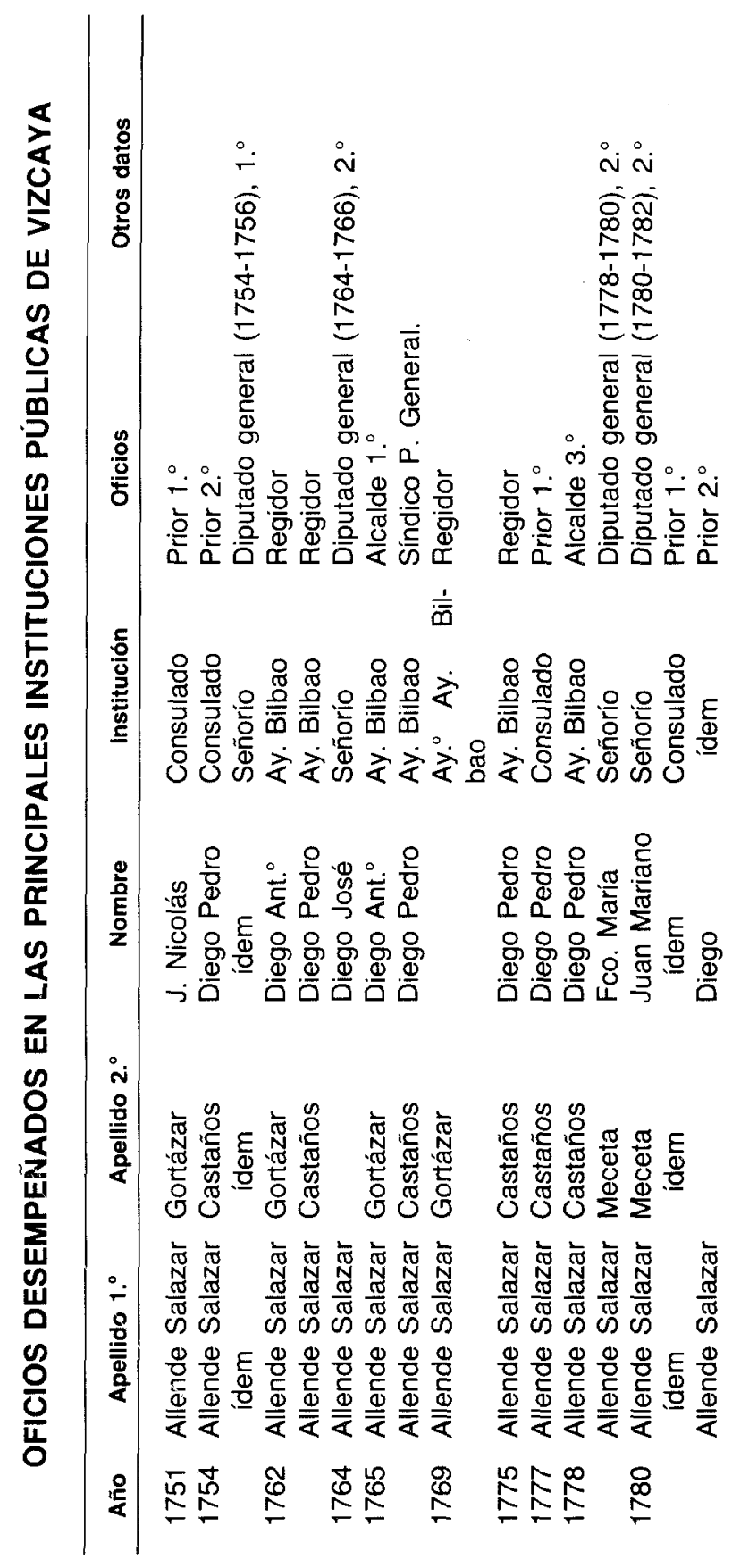




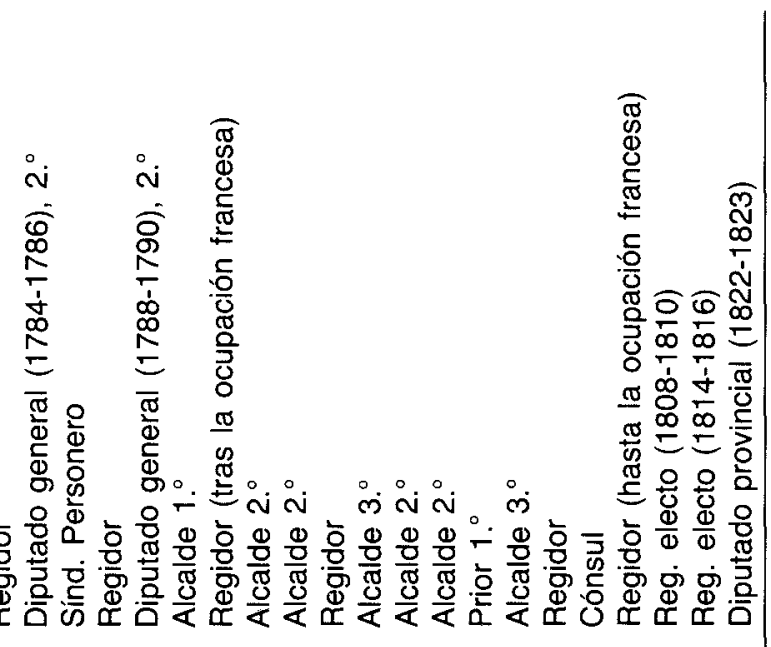

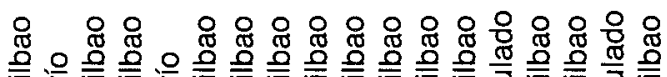

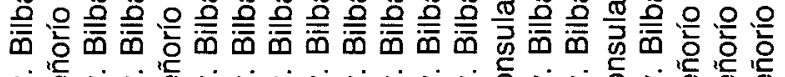

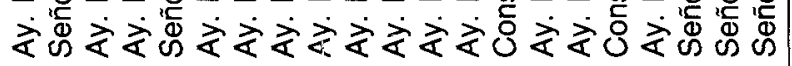

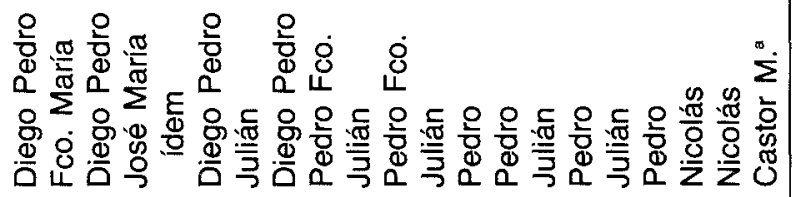

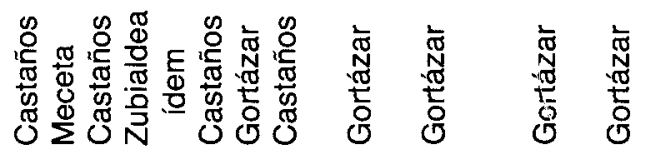

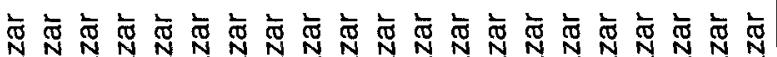

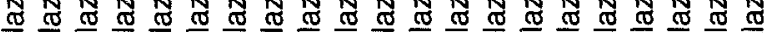
ららら 웜

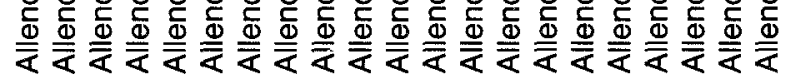

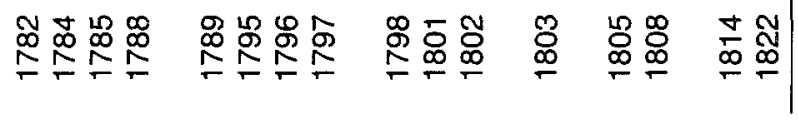




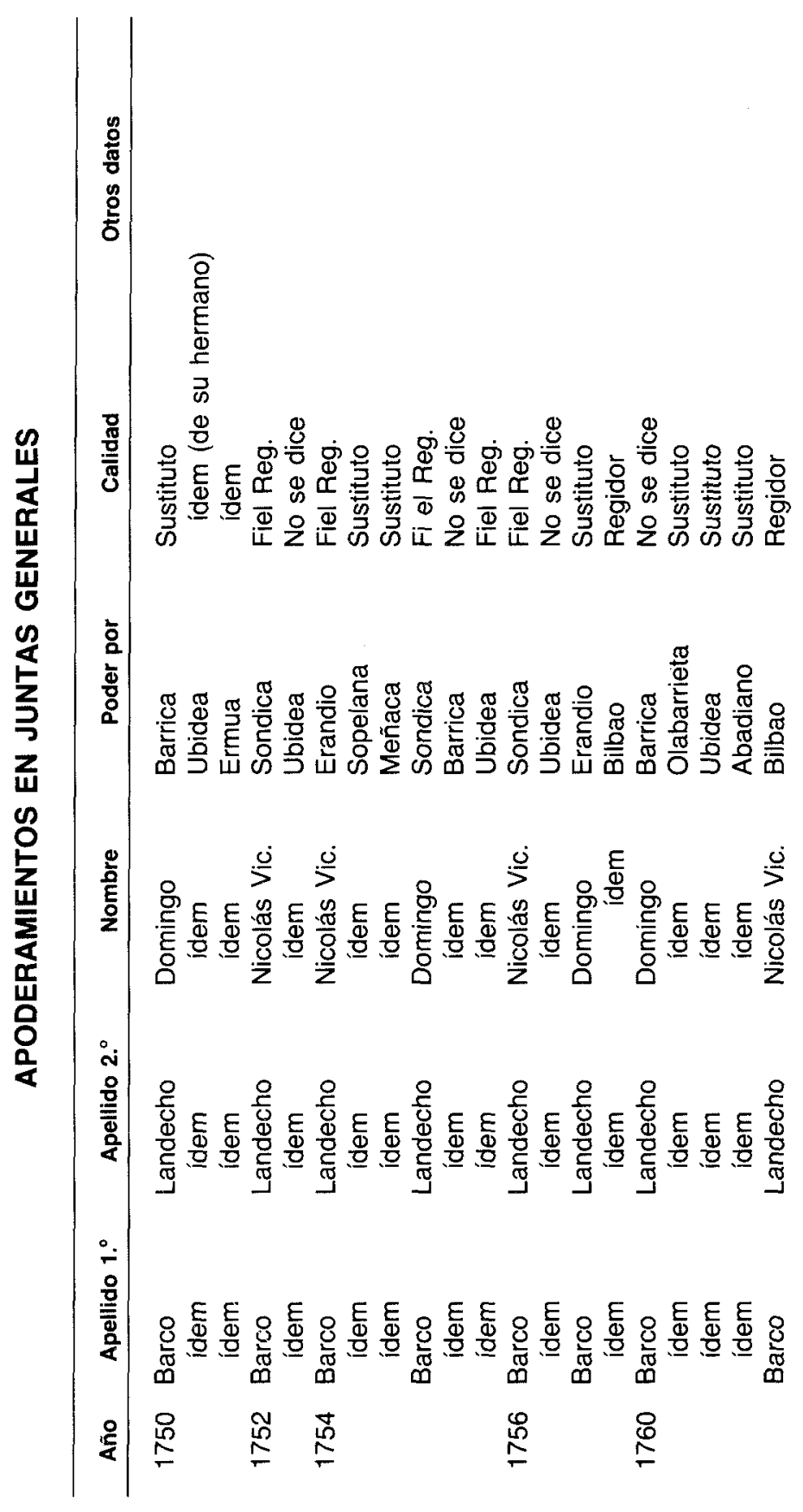




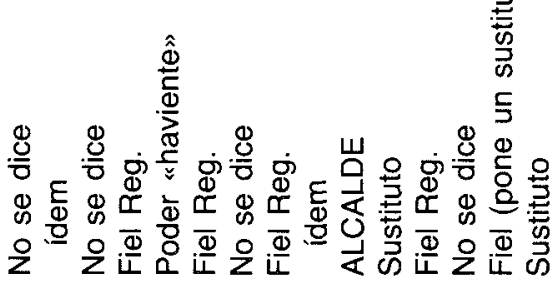

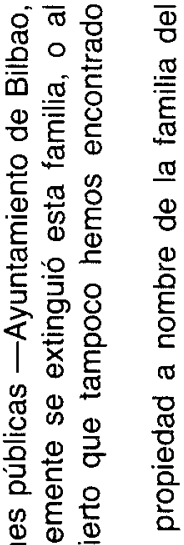

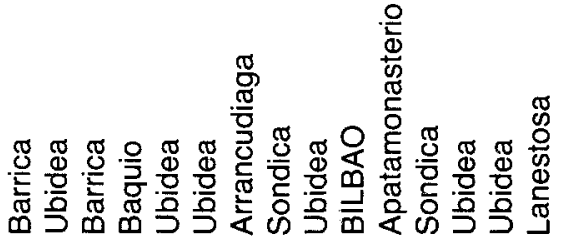

$\stackrel{\Phi}{\circ} \div \frac{\mathbb{0}}{0}$

을 을

들 얼

学

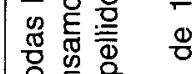

능 음

$\frac{10}{0} \overline{0}$

융

:응

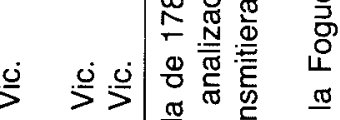

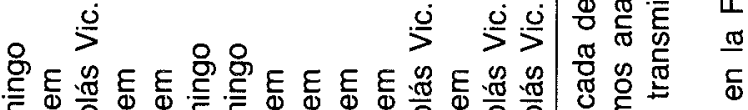

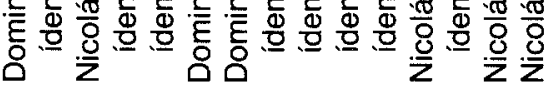

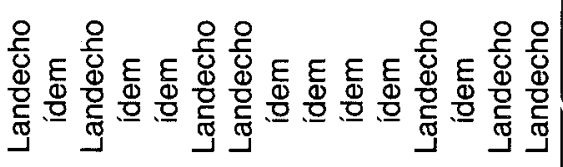

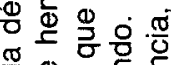

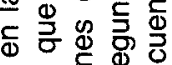
ه 1 인

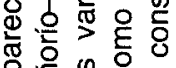
需, 융

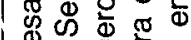

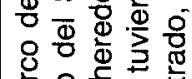

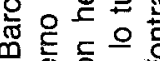

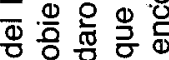

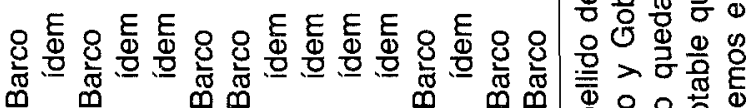

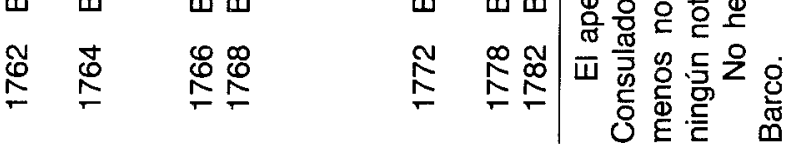




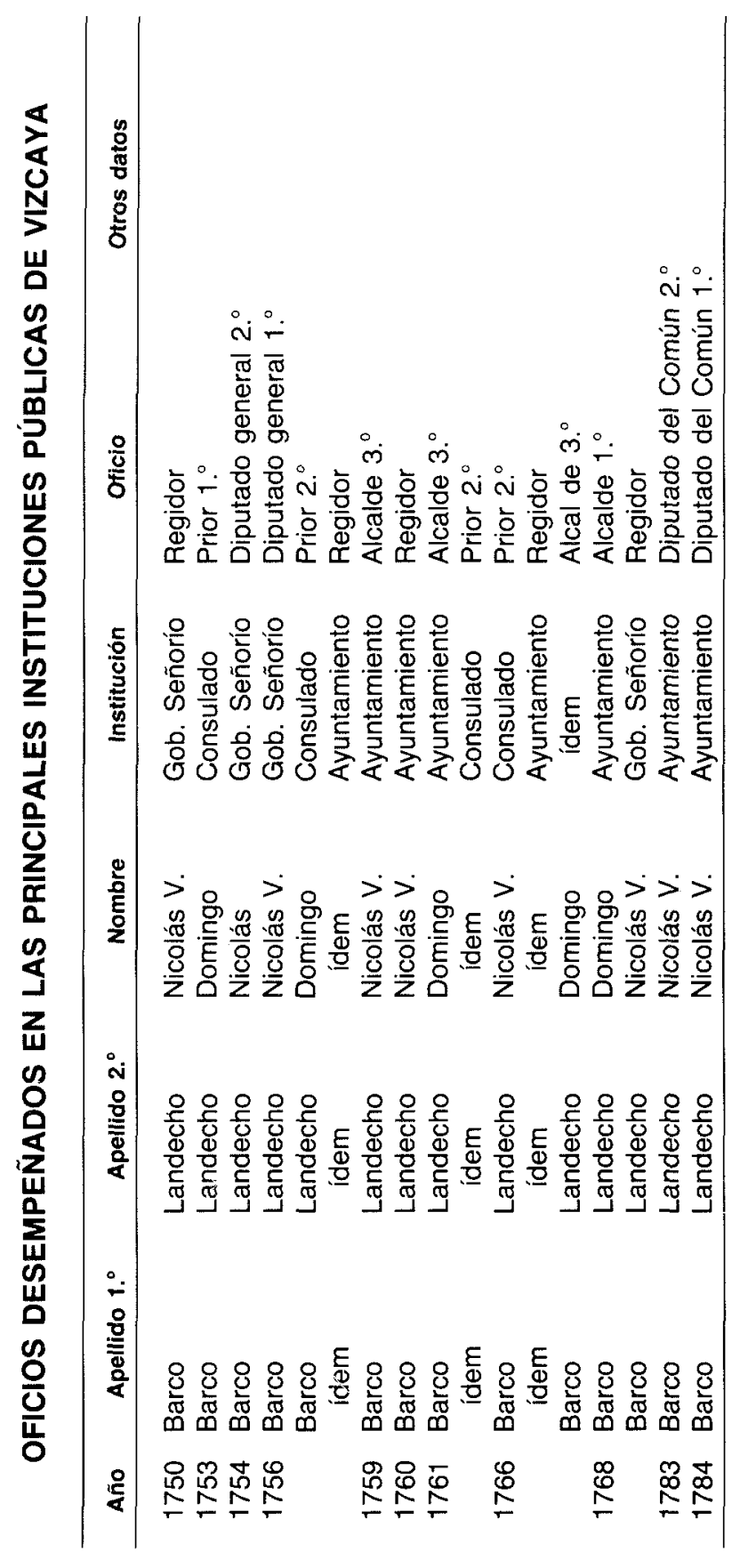

